\title{
Health and social status of Saudis retirees: A descriptive field study
}

\author{
Yaser Ahmed Helmy Khamis ${ }^{1 *}$ \\ ${ }^{1}$ King Saud University, KINGDOM OF SAUDI ARABLA, KSA
}

\begin{abstract}
This research aims to follow up ageing Saudis, their health and social status after retirement, and the main problems facing. The study sample was 650 people, 535 males and 115 females. About $95 \%$ of them married, $84 \%$ secondary educational level or less, and $89 \%$ of the sample were working in governmental or military sector, finally $61 \%$ of them retired due to age of 60 for civilian and 45 for military where $39 \%$ early retired especially for females. Although the overall health status has not changed before and after retirement but health status changed between both gender after retirement for females against males. Also the social characteristics before and after retirement for five main social problem indicate the existence of differences between males and females in the sense of social problems in favor of males and females understand more a sense of the problems, as well as increased sense of problems after retirement
\end{abstract}

\author{
Keywords \\ retirees in KSA, \\ health status, \\ social status \\ Received: 20 Jan 2016 \\ Revised: 15 Feb 2016 \\ Accepted: 3 Mar 2016 \\ DOI: $10.20897 /$ lectito.201614
}

\section{INTRODUCTION AND CONTEXT}

Human passes in his life from birth to death by a number of important ages like, childhood, adolescence, youth, and finally ageing. Each stage has a psychological, social and health changes. Through these stages human is trying to adapt to the nature of each stage, especially ageing stage, where human stopped work (retired), which consider one of the most important social outlets for a person followed by bad psychological state of the person. The government has an important role to assist this social category people in the adjustment, and adaptation with their retirement.

\section{RESEARCH PROBLEM}

The issue of elderly people and their retirement is one of the important communities of contemporary issues, especially with regard to the provision of health, economic, social and others services . In spite of this importance, the social status of the elderly vary greatly and clear among the members of this class of society, we find some of them accept life after retirement as it is began now, while others tend to social isolation as the end of his social role, and the rest ranging between these attributes. Also, there are a different views for men and women to retirement, and because of that there is a need to determine the health and social situation and follow-up each period of time to assess the current status and the future changes for Saudis retired, and to improve the services provided to them, with introduction of new services.

${ }^{*}$ Correspondence to: yasserhelmy72@yahoo.com

European Journal of Sociology and Anthropology, 2016. (C) 2016 Yaser Ahmed Helmy Khamis. This is an Open Access article distributed under the terms of the Creative Commons Attribution 4.0 International License

(http://creativecommons.org/licenses/by/4.0/), allowing third parties to copy and redistribute the material in any medium or format and to remix, transform, and build upon the material for any purpose, even commercially, provided the original work is properly cited and states its license. 


\section{RESEARCH IMPORTANCE}

This research cares by a stratified category of Saudis ageing, They are older people who began their numbers increase year after year, where statistics indicate that the number of Saudis who have reached 60 years and over in Saudi Arabia in 2004 was "836,707" and just $(211,016)$ of them survived, which represent rate of "25.2\%" (Department of Statistics, in 1425 AH-2004), while those of retired about $95 \%$ males and 5\% females. The number jumped in 2010 to "1.166 million" just $(362,424)$ of them survived, by rate of "31\%" of the total elderly (World population Prospects: The 2012 Revision), about 93.5\% of them males and $6.5 \%$ females, due to the economic boom (Oil Economic), and the increase in government employment in the Kingdom. As well as statistics show that the life expectancy of the individual (Life Expectancy) in Saudi Arabia has increased from (53.9) Years for males and 57 years for females in 1985 to (72.76) years for males and (76.37) years for females in 2010 (World population Prospects: The 2012 Revision). As a result of this change, the number of elderly is increasing continuously, Saudi Arabia and therefore increasing numbers of retirees, along with that of social change which result of the economic boom because of the oil sector growth has occurred has produced new patterns of social life, a lot of members of the community made it unable to handle, and has become an urgent need to assist some segments of society to pass some of those difficulties and problems faced by them and the retired category. As well as these changes have not kept pace appropriate action, which allows for senior General age, and retired them in particular, the different ways to satisfy the diverse needs, and overcome what caused the loss of work for them from the deterioration of their health as well as social, which makes this stage difficult for many retirees, has It came the importance of this research because it deals with this class, social and health characteristics affecting it and the results of their condition, in order to improve and renew them with appropriate services, social and health programs.

\section{RESEARCH AIMS}

This research aims to highlight on the ageing Saudis, their health and social status after retirement, the aim of this research in general try to get some knowledge about this group of the population: How they live their life? What are the health and social status? What are the most important factors affecting this situation?

\section{RESEARCH HYPOTHESIS}

In light of the theoretical framework of the research, and in line with the objectives of the research and the importance of this research will try to test the following hypotheses:

1- Health status for retirees between males and females does not differ.

2- Health status of retirees does not different before and after retirement.

3- Social status does not differ between Males and females.

4- Social status of retirees does not differ before and after retirement.

\section{RESEARCH TERMS}

\section{Retirees}

Retired employee: it has become in the retirement age, which was referred to the pension to receive a sum of money by administrative handed him in the service (Arabic Dictionary). A new definition is the result of several human and organizational social, political and economic factors resulted in the collapse of the feudal system and the industrial revolution in Western societies (al-Obeidi, 1989: 19), while retired in Saudi Arabia is every employee (civil / military) ended his tour of duty, and devoted to him Under the retirement pension systems, pension for his time.

\section{Health status}

What it is exposed after the retirement age of the individual (government - Soldier -Special) of symptoms or physical health lead to seek medical help for treatment of them (Al-Garib, 1995: 63). See Abu Hatab and honest that the individual after reaching the age of sixty or before just begins to note the deterioration of physical Foreign changes on his health and his body, which begins in the appearance of the body and its activity as a change of hair color, and the appearance of wrinkles and dry skin, general weakness and other outward appearances, all researchers agree that they innate and put God in human beings (Abu Hatab and 
honest1990: 616). It is a common disease in old age, hypertension, and diabetes, chronic arrest stage, diseases of the nervous system, and inflammation of the trachea, and other (back, 1986: 51). Progress in life result in health problems, but retirement is more than unit diseases and health problems as see Hashemi Weak physical capabilities or fall as a result of retirement leads to the deterioration of the health status of the retired, and become a victim of the disease, and the retired isolation on himself and his withdrawal from social life leads him to egocentrism and live in fear that affect the incidence of diseases (Hashemi 1979: 368). As al-Obeidi believes that retirees in Saudi Arabia when they reach the age of sixty reduced selfassessed health status compared with retired by choice, also found that the decline in pension and increasing age after retirement, and the lack of planning for post-retirement leads to poor health (al-Obeidi, 1989: 48). The researcher believes that the health situation of pensioners in Saudi Arabia can be viewed from two aspects: first, retired assess the health condition before and after retirement, reflecting the impact of psychological, economic and social aspects of the retired, the other side follow-up of chronic diseases among the retired category sample rates, distributions and how to evaluate the services provided to retirees.

\section{Social status}

Work is directly related to and influential social situation of the individual, which is one of the most important links between the individual and the community, especially for males. The work also finds AlGharib intrinsic part of a person's life affect his outlook on life, and so to the extent provided by the individual of social status, and affiliation of the individual to work is that individual feels important and loyalty to the organization who join it and his companions in a joint activity (Al-Gharib, 1995: 68). There are a lot of social problems facing retired, which can be classified into five types as follows (Al-Gharib, 1995: 69):

1. Roles and Social Status Problems.

2. Compatibility issues with the retirement stage.

3. Problems sense of social isolation.

4. Continue to work after retirement problems.

5. Leisure time problems

\section{LITERATURE REVIEW}

Study of (Rashid Mohammed Aba Al-Khail, 1991): PhD thesis entitled "Aging care social and health centers in the world as a model for ageing in the Kingdom of Saudi Arabia"

He provided a comprehensive vision of the center of social and health care for the elderly in the world, through the study of a number of private social centers for the elderly in Europe, Asia and North America (27 centers). He focused research on the quality of the activities and programs that provided in such centers and their suitability for the elderly Saudi Arabia, and reached out the importance of these centers in the provision of health and social care services and the satisfaction of vacuum elderly Times, which helps them to adapt with society and not feel isolated. He also searches to find a similar importance to these centers taking into account the specificity of the Kingdom of Saudi Arabian society.

\section{Study of (Ibrahim Al-Obeidi, 1989): A research paper titled "Retirees"}

He highlighted the phenomenon of retirement in the major cities in the Kingdom of Saudi Arabia through a sample of retirees gathered by Arab National Bank, which delivers all retirees in the Kingdom of monthly salaries. The aim of the research is to identify the characteristics of this group of Saudis, how they live their life? The problems faced? and the extent of their adaptation to this stage?. He reached out that retirees differ in the extent of their adaptation in the retirement phase, in the extent of their suffering to the problem of the vacuum, in the ability to compensate for the roles, and in the extent of their suffering financial problems. Also he found that $43 \%$ of the sample suffering from health problems, psychological problems, financial problems, and finally social problems.

Study of (Abdul Aziz Al-Gharib, 1995): A study titled "Retirees: Some of the social problems and the role of social service"

$\mathrm{He}$ gave attention to "Al-Gharib" study identifying problems resulting from retirement, and conducted research on a sample of (468) retired using the questionnaire, focused questions of the research and resolution on the problems associated with retirement, as well as on the relationship between 
the social characteristics of retired and a sense of social isolation and activities practiced by retired after retirement. He reached out that, pensioners in Saudi Arabia suffer from psychological problems, economic, social, and health problems. He stated that, their sense of social isolation varies from one person to another depending on their demographics characteristics. Also he found that, retired gives a chance to rework in a job after retirement, and it's varies depending on the demographic characteristics of age, social and economic situation of the person.

\section{Study of (Saleh Bin Mohammed Saghir, 1999): A research paper entitled "Life satisfaction among the elderly pensioners"}

He concentrated on the impact of social, economic, psychological and health determinants on the life satisfaction of ageing Saudis. He used a sample size of (432) retired from Riyadh using the questionnaire, also he studied work after retirement, sports and social activities practiced by Saudis retired. He reached out that, social, psychological, economic, health characteristics are the factors of life satisfaction, also the relationship between functional activities are good for life in this age, where the results emphasis on the older people who exercise and functionally active after retirement age more satisfied with their lives than retirees who do not work and have no functional activity after retirement.

\section{METHODOLOGICAL PROCEDURES TO SEARCH}

This research is a descriptive study aimed to identify the health and social characteristics of Saudis retirees, and the most important determinants and factors affecting positively or negatively on the relationship between these characteristics through a survey.

\section{Population and sample}

The total Saudi population in 2013 was $(19,838,448$ ), out of them there was in 2013 (about 617,070) retirees (Annual Statistical Report, 2013) alive and who represent the study population from the total population, the researcher had a representative sample of (650) retirees in a five areas in the Kingdom of Saudi Arabia as shown Table 1. The sample was selected within these areas at random, as sample size determination according to the equation of statistical representation to suggest that any community increases the number of its members about 100,000 individual can be represented by a single 384 sample research a good representation of the community according to the equation Sampson (1) (Allan, G. Bluman, 2009:205).

Table 1. Sample distribution by areas and gender

\begin{tabular}{|c|c|c|c|c|c|c|}
\hline \multirow{2}{*}{ Region } & \multicolumn{2}{|c|}{ Males } & \multicolumn{2}{|c|}{ Females } & \multicolumn{2}{|c|}{ Total } \\
\hline & $\mathrm{F}$ & $\%$ & $\mathrm{~F}$ & $\%$ & $\mathrm{~F}$ & $\%$ \\
\hline Riyadh & 300 & 56.07 & 55 & 47.83 & 355 & 54.62 \\
\hline Medina & 100 & 18.69 & 25 & 21.74 & 125 & 19.23 \\
\hline Jazan & 55 & 10.28 & 15 & 13.04 & 70 & 10.77 \\
\hline Eastern & 45 & 8.41 & 10 & 8.70 & 55 & 8.46 \\
\hline Jouf & 35 & 6.54 & 10 & 8.70 & 45 & 6.92 \\
\hline Total & 535 & 100.00 & 115 & 100.00 & 650 & 100.00 \\
\hline
\end{tabular}

\section{Research Tool}

The researcher adopted a questionnaire to collect data from a the sample, the questionnaire divided in two parts: the first part of demographic variables like age, salary before retirement and after retired, social status, educational status, and others, while the second part has included several questions to measure the main changes in health and social status of retirees, through some questions about family relations, and the relations of friendship, activity participation or social clubs, and the status of health of the respondent from his point of view.

\section{Validity and reliability}

To compute Validity and Reliability of the questionnaire, the researcher distributed the questioner to a group of academic specialists in the field of sociology at King Saud University, and the University of Imam. About $88.2 \%$ of them agree with the factors and questions. The researcher also distributed the questioner to a group of retirees and used SPSS program to extract the Cronbach's alpha coefficient and it reached 
(0.863). the researcher also used Statistical Package for Social Sciences (SPSS) to analyze the data and used the following statistical methods in this research: frequencies, percentages, $t$ test, and $f$ test.

\section{RESULTS}

The following are the main findings of research using a statistical analysis of the data, and represented in different types of tables with frequencies and percentages, also many tests were used like, $\mathrm{T}$ Tests and chisquared. The most important demographic characteristics of the sample, health status, and social status were introduced. Finally the hypotheses testing introduced to conclude the main points of the research, and at First demographic, health and social characteristics will be introduced:

\section{Demographic characteristics}

Table 2 represents the distribution of sample size depending on the age groups and gender, where the first age group was less than 50 years to illustrate military groups and early retirement, and increased to the category 75 years or more. It is clear from Table 2 that the $(13.2 \%)$ of the total sample size aged less than 50 years, where $30.5 \%$ of the total females sample aged less than 50 years, and $9.6 \%$ of the males sample. this high percentage for females explains early retire of Saudi females less than the official age of sixty because of the work conditions and the need of Saudi females to serve their families, and the percentage of males was normally distributed because of military retirement and early retirement according to the laws of the Kingdom. The second age group $(50-54)$ represented $(19.8 \%)$ of the total sample size, $(33 \%)$ of females sample and $(17 \%)$ of the males. The third age group $(55-59)$ represented $(18.8 \%)$ of the total sample, $(19.1 \%)$ for females sample, and (18.7\%) for males sample. It is clear that more than $(80 \%)$ of females retired before age 60 years, while for males just $(45 \%)$.

Table 3 shows the distribution of sample size marital status by gender, it is clear that the majority of the research sample are married by about $97 \%$, and the percentage was a little more to males about (98.5\%) of the males sample, and (89.5\%) for females.

Table 2. Sample distribution by age groups and gender

\begin{tabular}{|c|c|c|c|c|}
\hline \multicolumn{2}{|c|}{ Age Groups } & \multirow{2}{*}{$\begin{array}{c}\text { Males } \\
51\end{array}$} & \multirow{2}{*}{$\begin{array}{c}\text { Females } \\
35\end{array}$} & \multirow{2}{*}{$\begin{array}{c}\text { Total } \\
86\end{array}$} \\
\hline Less than 50 years & $\mathrm{F}$ & & & \\
\hline \multirow{3}{*}{$50-54$} & $\%$ & $9.60 \%$ & $30.50 \%$ & $13.20 \%$ \\
\hline & $\mathrm{F}$ & 91 & 38 & 129 \\
\hline & $\%$ & $17.00 \%$ & $33.00 \%$ & $19.80 \%$ \\
\hline \multirow[t]{2}{*}{$55-59$} & $\mathrm{~F}$ & 100 & 22 & 122 \\
\hline & $\%$ & $18.70 \%$ & $19.10 \%$ & $18.80 \%$ \\
\hline \multirow[t]{2}{*}{$60-64$} & $\mathrm{~F}$ & 116 & 14 & 130 \\
\hline & $\%$ & $21.70 \%$ & $12.20 \%$ & $20.00 \%$ \\
\hline \multirow[t]{2}{*}{$65-69$} & $\mathrm{~F}$ & 89 & 5 & 94 \\
\hline & $\%$ & $16.60 \%$ & $4.30 \%$ & $14.50 \%$ \\
\hline \multirow[t]{2}{*}{$70-74$} & $\mathrm{~F}$ & 58 & 0 & 58 \\
\hline & $\%$ & $10.80 \%$ & $0.00 \%$ & $8.90 \%$ \\
\hline \multirow[t]{2}{*}{75 and more } & $\mathrm{F}$ & 30 & 1 & 31 \\
\hline & $\%$ & $5.60 \%$ & $0.90 \%$ & $4.80 \%$ \\
\hline \multirow[t]{2}{*}{ Total } & $\mathrm{F}$ & 535 & 115 & 650 \\
\hline & $\%$ & $100.00 \%$ & $100.00 \%$ & $100.00 \%$ \\
\hline
\end{tabular}

Table 3. Sample distribution by marital status and gender

\begin{tabular}{|c|c|c|c|c|}
\hline \multicolumn{2}{|c|}{ Marital Status } & Males & Females & Total \\
\hline \multirow[t]{2}{*}{ Single } & $\mathrm{F}$ & 3 & 2 & 5 \\
\hline & $\%$ & $0.60 \%$ & $1.70 \%$ & $0.80 \%$ \\
\hline \multirow[t]{2}{*}{ Married } & $\mathrm{F}$ & 527 & 103 & 630 \\
\hline & $\%$ & $98.50 \%$ & $89.50 \%$ & $96.90 \%$ \\
\hline \multirow[t]{2}{*}{ Divorced } & $\mathrm{F}$ & 1 & 4 & 5 \\
\hline & $\%$ & $0.20 \%$ & $350 \%$ & $0.80 \%$ \\
\hline \multirow[t]{2}{*}{ Widowed } & $\mathrm{F}$ & 4 & 6 & 10 \\
\hline & $\%$ & $0.70 \%$ & $5.20 \%$ & $1.50 \%$ \\
\hline \multirow[t]{2}{*}{ Total } & $\mathrm{F}$ & 535 & 115 & 650 \\
\hline & $\%$ & $100.00 \%$ & $100.00 \%$ & $100.00 \%$ \\
\hline
\end{tabular}


Table 4 shows the distribution of sample size according to their education, about half of the research sample their education was preparatory or less, which represented about (55\%) of the sample. That percentage was high for males by about $65 \%$ out of the males, while it was so low for females about $(6 \%)$ because of high educational level of Saudi working females. While retired females ratio increased with secondary or university education to about $(91 \%)$ of females, and the proportion was less for males reaching about $(31 \%)$, probably because males need to work with various levels of education to support their families.

Table 5 represents sample distribution by labor sector, about $(47.8 \%)$ of the sample were working in governmental sector, especially all females were working in this sector, while $(36.6 \%)$ of male retirees were working in the governmental sector. The military sector was occupied just by males, and had a percentage of males reached about $(50.8 \%)$, while the private sector has accounted for about $12.5 \%$ of males. The distribution of sample size by labor sector was a good view for the economic situation of the kingdom, where the governmental and military sectors attracted all females, and about $90 \%$ of males, the private sector attracted just $12 \%$ of males latter on.

Table 6 shows the distribution of sample reasons for retirement, about $(42.6 \%)$ of males retired because of age of retirement for military sector, and while $(30 \%)$ of them retired because of the age of sixty. While about $(27.5 \%)$ of males, and $92 \%$ of females have retired early, depending on personal or government reasons.

\section{Health characteristics}

Table 7 represents sample distribution of health status according to their views after retirement, we find that about $29 \%$ of the respondents were of the view that their health had improved after retirement, especially females who retired early the percentage increased to about (49\%) between them, the impact of

Table 4. Educational status of the sample

\begin{tabular}{|c|c|c|c|c|}
\hline \multicolumn{2}{|c|}{ Educational Status } & Males & Females & Total \\
\hline Elementary or less & $\mathrm{F}$ & 260 & 4 & 264 \\
\hline & $\%$ & $48.60 \%$ & $350 \%$ & $40.60 \%$ \\
\hline Preparatory & $\mathrm{F}$ & 92 & 2 & 94 \\
\hline & $\%$ & $17.20 \%$ & $1.70 \%$ & $14.50 \%$ \\
\hline Secondary & $\mathrm{F}$ & 119 & 65 & 184 \\
\hline & $\%$ & $22.20 \%$ & $56.60 \%$ & $28.40 \%$ \\
\hline University & $\mathrm{F}$ & 50 & 40 & 90 \\
\hline & $\%$ & $9.30 \%$ & $34.80 \%$ & $13.80 \%$ \\
\hline Above University & $\mathrm{F}$ & 14 & 4 & 18 \\
\hline & $\%$ & $2.60 \%$ & $350 \%$ & $2.80 \%$ \\
\hline Total & $\mathrm{F}$ & 535 & 115 & 650 \\
\hline & $\%$ & $100.00 \%$ & $100.00 \%$ & $100.00 \%$ \\
\hline
\end{tabular}

Table 5. The distribution of sample search depending on the sector work

\begin{tabular}{|c|c|c|c|c|}
\hline \multicolumn{2}{|c|}{ Labor Sector } & \multirow{2}{*}{$\frac{\text { Males }}{196}$} & \multirow{2}{*}{$\frac{\text { Females }}{115}$} & \multirow{2}{*}{$\frac{\text { Total }}{311}$} \\
\hline Governmental Sector & $\mathrm{F}$ & & & \\
\hline \multirow{3}{*}{ Private Sector } & $\%$ & $36.60 \%$ & $100.00 \%$ & $47.80 \%$ \\
\hline & $\mathrm{F}$ & 67 & 0 & 67 \\
\hline & $\%$ & $12.50 \%$ & $0.00 \%$ & ten thirty $\%$ \\
\hline \multirow[t]{2}{*}{ Military Sector } & $\mathrm{F}$ & 272 & 0 & 272 \\
\hline & $\%$ & $50.80 \%$ & $0.00 \%$ & $41.80 \%$ \\
\hline \multirow[t]{2}{*}{ Total } & $\mathrm{F}$ & 535 & 115 & 650 \\
\hline & $\%$ & $100.00 \%$ & $100.00 \%$ & $100.00 \%$ \\
\hline
\end{tabular}

Table 6. Reasons for retirement of the sample

\begin{tabular}{|c|c|c|c|c|}
\hline \multicolumn{2}{|c|}{ Reasons for Retirement } & Males & Females & Total \\
\hline \multirow[t]{2}{*}{ Retirement Age for | Military } & $\mathrm{F}$ & 228 & 0 & 228 \\
\hline & $\%$ & $42.60 \%$ & $0.00 \%$ & $35.10 \%$ \\
\hline \multirow[t]{2}{*}{ Official Age of Retirement 60} & $\mathrm{~F}$ & 160 & 9 & 169 \\
\hline & $\%$ & $29.90 \%$ & $7.80 \%$ & $26.00 \%$ \\
\hline \multirow[t]{2}{*}{ Early Retirement } & $\mathrm{F}$ & 147 & 106 & 253 \\
\hline & $\%$ & $27.50 \%$ & $92.20 \%$ & $38.90 \%$ \\
\hline \multirow[t]{2}{*}{ Total } & $\mathrm{F}$ & 535 & 115 & 650 \\
\hline & $\%$ & $100.00 \%$ & $100.00 \%$ & $100.00 \%$ \\
\hline
\end{tabular}


early retired was a positive good for their health and for their big size families. while (41\%) of the total sample felt that their health has no change much after retirement especially retired males where the ratio increased to about $(44.5 \%)$. Finally over $(30 \%)$ of the sample stated that their health was better before retirement and retirement had a negative effect on their health. It is noted that retirement had a different effect between males and females, chi square test reached (29.6) at the level of significance $(0.000)$ which is less than 0.05 , It confirms the existence of clear differences between males and females retirees in health status, and this proves the first hypothesis of the research that" the health status changed between both gender".

Table 8 shows that there are a certain diseases distributed between sample persons, about $36 \%$ of the sample suffers from diabetes, while about $35 \%$ of the sample are suffering from pressure, about $(10 \%)$ suffers from heart disease, and about $18 \%$ suffers from other several diseases. It is clear that the largest percentage among males than females, due to a period of work and the pressure, difficulties of the work conditions. The percentage of patients before and after retirement was nearly the same, this confirms the interpretation of Second Hypothesis: that the overall health status has not changed before and after retirement.

\section{Social characteristics}

The researcher will deal with the main five social factor separately and will prove the third and fourth hypotheses for each factor and will start as follow:.

\section{Social roles and social state}

Table 9 shows the distribution of sample opinions about their social roles and social state after retirement, all the sample members are (Agree - Neutral - Disagree) that retirement change their social roles and state. The mean for the social state and roles factor reached about (1.95) for males with a standard deviation (0.737), and (1.77) for females with standard deviation (0.585), the difference between males and females was statistically significant and $T$ test reached (2.401) with level of significance $(0.017)$ which is less than (0.05), which indicates the existence of differences between males and females in the sense of the problems of social state and social role after retirement in favor of males and this proves the third hypothesis with respect to the factor of social state and roles between males and females.

Table 7. The health status of the sample individuals after retirement

\begin{tabular}{|c|c|c|c|c|}
\hline \multicolumn{2}{|c|}{ Health Status } & Males & Females & Total \\
\hline \multirow[t]{2}{*}{ Improved } & $\mathrm{F}$ & 130 & 56 & 186 \\
\hline & $\%$ & $24.30 \%$ & $48.70 \%$ & $28.60 \%$ \\
\hline \multirow[t]{2}{*}{ No Changed } & $\mathrm{F}$ & 238 & 28 & 266 \\
\hline & $\%$ & $44.50 \%$ & $24.30 \%$ & $40.90 \%$ \\
\hline \multirow[t]{2}{*}{ Decreased } & $\mathrm{F}$ & 167 & 31 & 198 \\
\hline & $\%$ & $31.20 \%$ & $27.00 \%$ & $30.50 \%$ \\
\hline \multirow[t]{2}{*}{ Total } & $\mathrm{F}$ & 535 & 115 & 650 \\
\hline & $\%$ & $100.00 \%$ & $100.00 \%$ & $100.00 \%$ \\
\hline Chi Square Test & 29.631 & Sign. & .000 & \\
\hline
\end{tabular}

Table 8. Distribution of diseases inside the sample

\begin{tabular}{|c|c|c|c|c|}
\hline \multicolumn{2}{|c|}{ Diseases } & Males & Females & Total \\
\hline \multirow[t]{2}{*}{ Diabetes } & $\mathrm{F}$ & 208 & 24 & 232 \\
\hline & $\%$ & $38.90 \%$ & $20.90 \%$ & $35.70 \%$ \\
\hline \multirow[t]{2}{*}{ Pressure } & $\mathrm{F}$ & 195 & 31 & 226 \\
\hline & $\%$ & $36.40 \%$ & $27.00 \%$ & $34.80 \%$ \\
\hline \multirow[t]{2}{*}{ Heart } & $\mathrm{F}$ & 51 & 9 & 60 \\
\hline & $\%$ & $9.50 \%$ & $7.80 \%$ & $9.20 \%$ \\
\hline \multirow[t]{2}{*}{ Others } & $\mathrm{F}$ & 97 & 20 & 117 \\
\hline & $\%$ & 14.92 & 3.08 & 18.00 \\
\hline
\end{tabular}

Table 9. Descriptive statistics and T test for social state and roles

\begin{tabular}{cccccc}
\hline Factor & Gender & Mean & $\begin{array}{c}\text { standard } \\
\text { deviation }\end{array}$ & T test & Sig. \\
\hline Social State and Roles & Males & 1.959 & .7379 & 2.401 & 0.017 \\
& Females & 1.772 & .5852 & & \\
Social State and Roles & Before retirement & 1.920 & 0.728 & 2.548 & .022 \\
& After retirement & 1.800 & .7414 & & \\
\hline
\end{tabular}


Also Table 9 shows that, there is a difference between the views of sample persons about social state and roles factor before and after retirement. The mean of that factor before retirement was (1.92) with standard deviation of (0.728), and after retirement the mean was (1.8) with deviation standard of (0.741) for the whole sample. T test between both was (2. 548), with level of significant $(0.022)$, which less than $(0.05)$, that explain the difference between both views before and after retirement, and this proves the fourth hypothesis about the social roles and state before and after retirement. With emphasis upon the high social roles before retirement that after. It is one of the important social problems in the lives of retirees. However, we must here point out the importance of the role of the family, especially the extended family in the care of the elderly, where the family is considered the field of retired or retired attention which helps them greatly to overcome these problems after retirement, especially retired to feel that you care about his family and serve the side of religious moral making it feel comfortable. But researcher refers to the importance of the existence of clubs or associations to take care of the elderly and directing skills and hobbies and provide gathering activities.

\section{Compatibility issues with retirement stage}

Table 10 represents the distribution of opinions of the sample with respect to the second factor of compatibility, the mean was about (1.9 3) for males in that factor, with a standard deviation of $(0.7$ 62). While the mean of the females was about (1.7 1), with deviation standard of $(0.579)$, and noted the presence of statistically significant differences between males and females with $T$ test value of (2.772), with level of significance $(0.006)$ which is less than $(0.05)$, which indicates the existence of differences between males and females in the sense of the problems of compatibility.

Also there is a clear difference between the opinions of sample persons about the second factor of compatibility social before and after retirement, where the mean of that factor before retirement was (1.9), with standard deviation of (0.7418), and the mean was (1.859) after retirement, with a standard deviation of (0.67). T test confirmed that there is a statistical difference between both, with $t$ value of (2.826), and level of significance about (0.005) which is less than (0.05).

\section{Sense of social isolation}

Table 11 shows the sample distribution opinions about sense of social isolation factor, the mean was (1.96) for males, with a standard deviation of (0.75). While the mean of females was about (1.68), with deviation standard of $(0.545)$, and noted the presence of statistically significant difference between males and females by $\mathrm{T}$ test. The value of $\mathrm{T}$ test reached (3.515), with level of significance (0.000) which is less than (0.05), which indicates the existence of difference between males and females in the sense of isolation after retirement in favor of males, who are facing that problem more than females.

Also There is a clear difference between sample opinions about the feeling of social isolation before, and after retirement, the mean of the sample before retirement was (1.92), with standard deviation of (0.729). The mean for the sample after retirement was about (1.86), with standard deviation of (0.67), there was a difference between both means before and after retirement opinions about social isolation factor and $\mathrm{T}$ test reached about (3.862), with level of significance reached (0.000) which is less than (0.05) and that emphasis upon the difference. We can note that although the statistical difference before and after but the two mean were so closed, that explain that Saudi retirees already made their isolation problem before retirement.

Table 10. Descriptive statistics and $T$ Test for compatibility factor

\begin{tabular}{|c|c|c|c|c|c|}
\hline Factor & Gender & mean & $\begin{array}{l}\text { standard } \\
\text { deviation }\end{array}$ & T test & Sig. \\
\hline Compatibility Factor & $\begin{array}{c}\text { Males } \\
\text { Females }\end{array}$ & $\begin{array}{l}1.934 \\
1.712\end{array}$ & $\begin{array}{l}.7628 \\
.5797\end{array}$ & 2.772 & 0.006 \\
\hline Compatibility Factor & $\begin{array}{l}\text { Before retirement } \\
\text { After retirement }\end{array}$ & $\begin{array}{l}1.900 \\
1.859\end{array}$ & $\begin{array}{l}.7418 \\
0.6700\end{array}$ & 2.826 & .005 \\
\hline
\end{tabular}

Table 11. Descriptive statistics and $\mathrm{T}$ Test for sense of social isolation factor

\begin{tabular}{|c|c|c|c|c|c|}
\hline Factor & Gender & mean & $\begin{array}{l}\text { standard } \\
\text { deviation }\end{array}$ & T test & Sig. \\
\hline \multirow[t]{2}{*}{ Sense of Social Isolation } & Males & 1.96210 & 0.750046 & 3.515 & .000 \\
\hline & Females & 1.68585 & 0.545696 & & \\
\hline \multirow[t]{2}{*}{ Sense of Social Isolation } & Before retirement & 1.92 & 0.729 & 3.862 & .000 \\
\hline & After retirement & 1.859 & 0.670 & & \\
\hline
\end{tabular}




\section{Continue working after retirement}

Table 12 represents the average salary before retirement for males retirees reached (12,563 SR monthly), and about (11,626 SR monthly) for females, and notes that there is not a significant difference between males and females in their salaries, with $T$ test value (.836), and level of significance (0.404) which is greater than (0.05). That indicates that there is no difference between males and females.

Also the average salary after retirement for males reached (8,581 SR monthly), and about (7,777 SR monthly) for females, and notes that there is not a significant difference between males and females in their salaries after retirement, with $\mathrm{T}$ test value (.993), and level of significance (0.321) which is greater than (0.05). That indicates that there is no difference between males and females.

On the other hand, the average salary before retirement for the whole sample was about $(10,037 \mathrm{SR}$ monthly), with a standard deviation of (5665.7), and the average salary value after retirement for the whole sample was about (7,221 SR monthly), with standard deviation of (4553). We can note that there is a clear difference between the averages of salaries before and after retirement, the value of $\mathrm{t}$ teat reached (18.16), with level of significance of (.000) and it is less than (0.05). There is a statistically significant difference between the salary before and after retirement, the difference was nearly ( 3 thousand SR), which makes the financial problems, and that may push the retirees to work after retirement.

\section{Leisure time}

Table 13 shows the distribution of sample opinions about the existence of a plan for what you will do after retirement, we find that just about $(25 \%)$ of the sample had a plan, while $(75 \%)$ not planned for that stage of their life. This ratio for females is more than males, chi square test value was (4.767), with level of significance (0.029) which is less than 0.05 , which demonstrates the existence of differences between males and females in developing a plan for after retirement in favor of males. Also Table 13 shows that, free time problem in the life of retirees after retirement must has a great attention to this people in terms of providing some health and social clubs, or associations that can gathering and regrouped them in appropriate activities, especially that fit their hobbies and skills.

\section{CONCLUSIONS AND RECOMMENDATIONS}

This research aims to highlight retired status, their Health and social conditions after retirement, The researcher used descriptive method on a sample of 650 person, 115 females, and 535 males retirees, spread over five regions of the Saudi Kingdom. The researcher reached several conclusions, including that about $29 \%$ of the respondents were of the view that their health has increased improvement after retirement, especially retirees who among them increased to about (49\%) means that retirement has a good positive impact on their health and that of her interest in family matters and House Only without going to work, while $(41 \%)$ of the sample felt that their health has not changed much after retirement especially retired male where the ratio rose have to about $(44.5 \%)$, while over $30 \%$ of the research sample that their health was better before any retirement pension that has a negative effect on their health. And it confirms the square test value

Table 12. Descriptive statistics and $T$ test for salary of retirees

\begin{tabular}{cccccc}
\hline Salary & Gender & mean & standard deviation & T test & Sig. \\
\hline Salary Before Retirement & Males & 12563.17 & 10562.610 & 0.836 & 0.404 \\
& Females & 11626.85 & 4565.611 & & \\
Salary After Retirement & Males & 8581.70 & 7658.887 & 0.993 & 0.321 \\
& Females & 7777.01 & 4468.706 & & \multirow{2}{*}{000} \\
Monthly Salary & Before retirement & 10037 & 5665.7 & & \\
& After retirement & 7220.9 & 4553.28 & & \\
\hline
\end{tabular}

Table 13. Sample distribution about planning after retirement

\begin{tabular}{|c|c|c|c|c|}
\hline \multirow{2}{*}{\multicolumn{2}{|c|}{ Have a Plan }} & \multicolumn{2}{|c|}{ Gender } & \multirow[t]{2}{*}{ Total } \\
\hline & & Females & Males & \\
\hline \multirow[t]{2}{*}{ Yes } & $\mathrm{F}$ & 19 & 140 & 159 \\
\hline & $\%$ & $16.50 \%$ & $26.20 \%$ & $24.50 \%$ \\
\hline \multirow[t]{2}{*}{ No } & $\mathrm{F}$ & 96 & 395 & 491 \\
\hline & $\%$ & $83.50 \%$ & $73.80 \%$ & $75.50 \%$ \\
\hline \multirow[t]{2}{*}{ Total } & $\mathrm{F}$ & 115 & 535 & 650 \\
\hline & $\%$ & $100.00 \%$ & $100.00 \%$ & $100.00 \%$ \\
\hline Chi square & 4.767 & \multicolumn{2}{|c|}{ Sign. } & 0.029 \\
\hline
\end{tabular}


like any other, which amounted to (29.6) at the level of significance $(0.000)$ which is less than 0.05 , which confirms the existence of clear differences between males and females retirees in health status, and the relative distribution that demonstrates similar to the first descent (increased improvement) and third (The best pre-retirement) shows a lack of health status differences before and after retirement. Also found that, the sample views of social characteristics before and after retirement about five main social problem indicate the existence of differences between males and females in the sense of social problems in favor of males and females understand more a sense of the problems, as well as increased sense of problems after retirement. Research recommends to emphasize the importance of the role of family in the care of the elderly through various media, in mosques and religious sermons, as recommended by the importance of the existence of clubs or associations to take care of the elderly and directing skills and hobbies and provide gathering activities.

\section{REFERENCES}

Aba Al-Khail, M.R., 1991. Aging and elderly care centers in the world: a social health center for the elderly in the Kingdom of Saudi Arabia model. Ruyadh: Unpublished Ph.D. - Riyadh al-Sharif Presses.

Abdul Hamid, A.M., 1986. Social Work in the field of care for the elderly. Cairo: Middle Renaissance Library.

Atchley, R.C., 1971. Retirement And Leisure Participation: Continuity or Crisis?. The Gerontologist, 11(1), pp.13-17.

Atchley, R.C., 1989. A Continuity Theory Of Normal Aging. The Gerontologist, 29(2), pp.183-190.

Atchley, R.C., 1999. Continuity and Adaptation in Aging: Creating Positive Experiences. Hopkins University Press of Johns.

Cumming, E. and William, E.H., 1961. Growing Old. New York: Basic. pp.227.

Hashemi, A.H., 1979. Psychology formative. Riyadh:Dar Al Huda publication.

Havighurst, R.J., Neugarten, B.L. and Tobin, S.S., 1968. Disengagement and patterns of aging. In B.L.

Ibrahim, S.S., 1999. Social, psychological, economic and health determinants influencing the level of satisfaction with life in the elderly retirees: Analytical Field Study in Riyadh. Riyadh: King Saud University, Faculty of Arts.

Ibrahim, T., 1984. Professional status and motives of work. Riyadh: King Saud University, Faculty of Arts.

Khamis, A., 1989. Elderly care programs and the role of the social service. (Master dissertation, KING SAUD UNIVERSITY).

Miller, S., 1965. The social dilemma of the aging leisure participant. In A.M. Rose and W.A. Peterson (Eds.), Older people and their social world. Philadelphia: Davis. pp.79-92.

Neugarten (Ed.), Middle age and aging: A reader in social psychology. Chicago: University of Chicago Press. pp.161-172.

Obeidi, L., 1989. Pensioners. Riyadh: Ministry of Interior to combat Research Center Jerimh.

http://www.almaany.com/ar/dict/ar-ar http://www.pension.gov.sa/Pages/default.aspx

http://esa.un.org/wpp/Excel-Data/mortality.htm 